\title{
Evidential Imperatives in Election Petitions in Nigeria
}

\author{
E.Q. Okolie Esq
}

\begin{abstract}
Election Petition is the only viable and reorganized alternative open to any person or party dissatisfied with the conduct of an election under our laws to ventilate his or her grievances. Over the years, litigants/petitioners have continued to patronize the election petition tribunals/courts with minimal or no success as most of the petitions ended up being thrown out for non-compliance with the applicable electoral legislations or want of proof. The objective of this paper is to examine why it is a near impossibility to prove election petitions anchored on some grounds and also to proffer away out. The paper also advocates by way of recommendation that the electoral umpire (INEC) and judges should uphold substantial justice over and above technicalities; further, the requirement of proof of non-compliance should be made optional or a mid-course approach be adopted in proof of corrupt practices instead of proof beyond reasonable doubt in cases of allegations that have criminal undertone as currently practiced in Nigeria. It is hoped that by the mid-course approach with respect to proof of corrupt practices, the mere fact that it can be established that an election is riddled with corrupt practices, should be sufficient to void such an election without necessarily proving substantial non-compliance with the relevant provisions of the Electoral Act and other laws on that behalf; and without also necessarily establishing the link between the Respondent and the person(s) who carried out the alleged corrupt practices, et cetera.
\end{abstract}

Index Terms- Election, Nigeria, Petition, Tribunal

\section{INTRODUCTION}

This paper shall discuss the evidential imperatives as it relates to proceedings in election petitions, including but not limited to the type/form of evidence required in order to succeed in an election petition. This will entail looking at the pleadings and evidence, burden of proof of corrupt practices/Electoral malpractices and standard of proof as required for the petitioner to succeed in an election petition, with a view to ascertaining whether the evidence required affords electoral justice.

\section{PLEADINGS AND EVIDENCE}

The Black's Law Dictionary ${ }^{1}$ defines pleading as a formal document in which a party to a legal proceeding sets forth or responds to allegations, claims, denials, or defences. The object of pleadings is to fix the issue for trial accurately and to appraise the other side of the case which it would meet in court $^{2}$. So the principal purpose of pleadings is to set out clearly the facts relied on by one of the parties to a case in

E.Q. Okolie Esq, Senior Lecturer and Former Head of Department, Faculty of Law, Chukwuemeka Odumegwu Ojukwu University, Igbariam Campus, Anambra State, Nigeria

' BA Gamer (ed), Black's Law Dictionary ( $9^{\text {th }}$ edn, USA: West Publishing Co, 2009), p. 1191

${ }^{2}$ PA Onamade, Documentary Evidence - Cases and Materials (Vol. 1, Lagos: Philade Co Ltd, 2002), p. 446 support of his claim so that the opposite party may not be taken by surprise. It should be sufficient, comprehensive and accurate. ${ }^{3}$ Rhodes Vivour, JSC in Al-Hassan v Ishaku ${ }^{4}$ stated as follows:

... The main aim of pleading is to convey the case and the claim of the plaintiff (petitioner) to the defendant $\left(1^{\text {st }}\right.$ respondent). In this way the defendant would not be taken by surprise. He would either admit the claim or present his own defence. So if pleadings are to be of any use parties and the court are bound by them. See Adesanya $v$ Aderonmu (2000) 13 WRN 104; [2000] 9 NWLR (pt 672) 370, Echir v Nnamani (2000) 4 WRN 79; [2000] 8 NWLR (pt 667) 1; Ogbogu v Ugwuegbu [2003] 10 NWLR (pt. 827) 189; Makinde $v$ Akinwale [2000] 2 NWLR (pt. 645) 435. On no account would a party be allowed to contend the contrary.

Therefore at the trial stage of the action, both parties are bound by their pleadings and it is elementary that admissions in pleadings do not have to be proved. In so far as pleadings do not contain admissions, then the matter alleged must be proved in evidence, but the evidence cannot derogate from the pleadings.

Also, a petitioner in an election petition must call evidence in support of his pleadings and any evidence which is adduced contrary to the pleadings should never be admitted. ${ }^{5}$ In Buhari $v$ Obasanjo $^{6}$ the Supreme Court held that parties are bound by their pleadings and evidence not supported by the pleadings goes to no issue and must be discountenanced. In that case, the appellants pleaded that electoral malpractices occurred in 14 States of the federation. Consequently, evidence adduced in respect of States not pleaded were held as going to no issue and the Court of Appeal sitting as the Presidential Election Tribunal was right when it held that the election in 22 States of the Federation not mentioned was properly conducted.

${ }^{4}$ (2016) 9 WRN 1, at (pp. 21-22) lines 45-10; [2016] 10 NWLR (pt 1520) 230 at $264 \mathrm{SC}$.

5 See Abdullahi v Elayo [1993] 1 NWLR (pt 268) 141.

6 [2005] NWLR (pt 876)1. 
The law is clear and settled that pleading is not synonymous with evidence and so cannot be construed as such in the determination of the merit or otherwise of a case. A party who seeks judgment in his favour (that is, the petitioner) is required by law to produce adequate credible evidence in support of his pleadings, and where there is none then the averment in the pleadings are deemed abandoned. The same principle of law goes for whatever defence a defendant seeks to rely on in the process of demolishing the case against him. The above principle of law applies to election petition cases. The respondent is not bound by law to call a witness or witnesses to establish his defence where a prima facie case has not been proved by the petitioner, but that position is valid only if a prima facie case has not been established by the party in whose favour judgment will be given if he fails to adduce evidence. ${ }^{7} \mathrm{We}$ shall now proceed to look at the grounds constituting the election petition which the petitioner must prove for him to succeed:

\section{III.GROUNDS OF ELECTION PETITION}

In delving into evidential imperatives in election petitions, it is pertinent to ascertain the grounds upon which election petition could be challenged. This is because other issues like substantial noncompliance, corrupt practices and malpractices, et cetera all revolve therein. You cannot claim to have succeeded in proving an election petition without specifically succeeding on any of the grounds of your petition. Thus, section 138 of the $\mathrm{Act}^{8}$ provides thus:

"(1) An election may be questioned on any of the following grounds, that is to say -

(a) that a person whose election is questioned was, at the time of the election, not qualified to contest the election;

(b) that the election was invalid by reason of corrupt practices or noncompliance with the provisions of this Act;

(c) that the respondent was not duly elected by majority of lawful votes cast at the election; or

(d) that the petitioner or its candidate was validly nominated but was unlawfully excluded from the election. $^{9}$

After looking at the grounds of election petition, we shall look at the onus/burden of proof and standard of proof by way of evidential imperatives as required in establishing the grounds as a separate topic. Now, it is pertinent to adumbrate on the above-stated grounds:

\section{Non-Qualification}

Section 138(1)(a) of the $\mathrm{Act}^{10}$ provides: "that a person whose election is questioned was, at the time of the election, not qualified to contest the election"

${ }^{7}$ See section 137 of the Evidence Act, Laws of the Federation of Nigeria 1990 Cap. 112. See also Arabambi

Anor v Advance Beverages Ind. Ltd 24 NSCQR 520 at 547.

${ }^{8}$ Electoral Act, 2010 (as amended).

${ }^{9}$ See generally Gwede v INEC [2014] 18 NWLR (pt 1438) 56; Ucha v Elechi [2012] 13 NWLR (pt 1317) 330.

${ }^{10}$ Ibid
It is settled that election petition must emanate from act(s) that happened during the election or contemporaneous with an election. The act(s) must have happened during and/or after the holding of an election otherwise the act(s) will be a pre-election matter, which ordinarily resides within the domain of regular courts, and which the election tribunal/court does not have jurisdiction to entertain. From the foregoing, it could be seen that ground 138(1)(a) deals with issue of "qualification" of a person who has been declared a winner of an election and returned as such. It is the opinion of the researcher that this is an exception to the rule. The ground empowers the petitioner to question the qualification of the respondent; the qualification before the holding of the election being complained of. Hence, the non-qualification must have happened before the holding of the election. It does not include the issue of nomination and sponsorship of a candidate by his/her political party.

In Al-Hassan $v$ Ishaku ${ }^{11}$, Al-Hassan challenged the nomination of Governor Ishaku of Taraba State on the ground that Ishaku was not the duly nominated candidate of the Peoples Democratic Party (PDP) in the 2015 general elections, among others. One of the issues raised therein with respect to section 138(1(a) was on how a candidate at election petition can challenge an election on the ground that the winner of the election was not qualified to contest the said election. The Supreme Court held that a person who participated in an election and desires to challenge the election of the winner on the ground that the winner was not qualified to contest the election can do so only under section 177 of the 1999 Constitution, if he failed to do so under section 31(5) and (6) of the Electoral Act, 2010. The Supreme Court further went on by saying that by virtue of section 31(5) and (6) of the Electoral Act, 2010, any person who has reasonable grounds to believe that any information given by a candidate in an affidavit or any document submitted by that candidate is false may file a suit at the Federal High Court, High Court of a State or Federal Capital Territory Abuja against such person seeking a declaration that the information contained in the affidavit is false. If the court determines that any of the information contained in the affidavit or any document submitted by that candidate is false, the court shall issue an order disqualifying the candidate from contesting the election.

Also in the same case ${ }^{12}$, one of the issues was on whether election tribunal can inquire into primary election of a political party. It was held that by virtue of section 138(1)(a) of the Electoral Act, 2010, the power of an election tribunal to decide whether a person is qualified to contest an election is restricted to establishing the requirements of sections 177 and 182 of the 1999 Constitution against the adverse party. An election tribunal has no jurisdiction to inquire into the primaries of a political party. It has no jurisdiction to comment or examine how party primaries were conducted. It went on to hold that jurisdiction for such an exercise resides with the Federal High Court, the High Court of a State, or the High Court of the Federal Capital Territory and only at the instance of a dissatisfied aspirant at the primaries.

Hence, the writer found out that the law has not changed: a person's disqualification or non-qualification based on or arising from the domestic nomination exercise of

\footnotetext{
${ }^{11}$ Supra at 264 SC.

${ }^{12}$ Al-Hassan v Ishaku (supra) at pp. 264; 265-266.
} 
his political party is a pre-election matter over which the election tribunal has no jurisdiction. The ground envisaged by section 138(1)(a) is not one of those areas. The grounds envisaged here for election tribunal/court to have jurisdiction could emanate from sections 177 and 182 of the Constitution with respect to governorship election petition or sections 131 and 137 of the Constitution with respect to presidential election petition, among others, if the challenger did not utilise the provisions of section 31(5) and (6) of the Electoral Act, 2010 (as amended), which would have taken the challenger to the regular courts before the holding of the election.

Furthermore, it is to be noted that the effect of successful challenge by the petitioner on this ground [section 138(1)(a) of the Electoral $\mathrm{Act}^{13}$ ] will warrant a fresh election. This is in tandem with section 140(2) of the Act, ${ }^{14}$

\section{INVALID ELECTION}

Ground 138(1)(b) of the Act provides: "that the election was invalid by reason of corrupt practices or non-compliance with the provisions of this Act". More so, it is pertinent to stretch further that it is not enough to allege noncompliance. The noncompliance is subjective (subject to the discretion of the court or the tribunal); and the noncompliance must be "substantial". ${ }^{15}$ Thus, section 139(1) of the Act ${ }^{16}$ also provides thus:

An election shall not be liable to be invalidated by reason of noncompliance with the provisions of this Act if it appears to the Election Tribunal or Court that the election was conducted substantially in accordance with the principles of this Act and that the noncompliance did not affect substantially the result of the election.

\section{What is non-compliance?}

The term "non-compliance" has not been defined in any part of the Electoral Act and has left us with no choice than to look for its meaning outside the Act. Non-compliance with the Electoral Act in relation to an election may be defined as the conduct of an election contrary to the prescribed mode under the Act or rules and regulation made thereunder. Noncompliance may result not only from the degree of, but also from the nature of the complaint; and the question in every case is, whether or not in view of the findings, the constituency or State as much was allowed to elect its representative. $^{17}$

In Ojukwu v Yar 'Adua ${ }^{18}$ the Supreme

Court defines compliance thus:

Compliance, ordinarily, is an act of complying or acting in accordance with the wishes, requests, demands, requirements, condition or orders. It is an act of yielding to the requirements or order. It is also an act of submission, obedience and conformance. On the

\footnotetext{
${ }^{13}$ Ibid.

${ }^{14}$ Ibid

${ }^{15}$ Emphasis supplied.

${ }^{16}$ Ibid.

${ }^{17}$ Nwole v Iwuagwu [2004] 15 NWLR (pt 895) 61.

18 [2008] All FWLR (pt 408) 1409.
}

other hand, non-compliance is a reversal of all what compliance is.

The Electoral Act ${ }^{19}$ provides for the rules for the conduct of election in what it termed "procedure at election." The rules address inter alia; the hour of poll, ${ }^{20}$ issue of ballot paper, ${ }^{21}$ mode of queuing, ${ }^{22}$ conduct of poll by open secret ballot, ${ }^{23}$ one man one vote, ${ }^{24}$ ballot not be marked by voter for identification, ${ }^{25}$ conduct at polling station, ${ }^{26}$ closing of poll, ${ }^{27}$ counting of votes and entering of scores in prescribed form, ${ }^{28}$ recount, collation of result, ${ }^{29}$ rejection of ballot paper without mark, ${ }^{30}$ endorsement on rejected ballot, ${ }^{31}$ declaration of result $^{32}$ among other procedures. It is required that these rules and regulations should be complied with. Failure to comply with or disregard any of these rules would constitute an instance of non-compliance with the Electoral Act and therefore likely to be a basis for an election petition found on non-compliance.

Generally, where in an election petition a petitioner makes an allegation of non-compliance with the Electoral Act as a basis or foundation of his case, he has a duty and heavy one for that matter to show the tribunal cogent and compelling evidence that the alleged non-compliance is of such a nature as to affect the result of the election. In Agboola v Fata ${ }^{33}$ Abubakar, JCA has this to say:

In order to establish non-compliance that would affect the result of the election, the appellant must prove the allegations and then go ahead by the same evidence to show that, the non-compliance had substantially affected the result of the election, failure to do so by the appellant would automatically defeat the petition. See Buhari v INEC (2008) 11 WRN 36; [2008] 4 NWLR (pt 1078) 546.

This is the net effect of Section 139(1) of the Act. ${ }^{34}$ The implication of this is that for an election to be upheld by the court as a valid election, it must have been conducted in substantial compliance with the law. To determine whether an election was conducted in substantial compliance or substantial non-compliance, the requirements of substantial compliance must first of all be determined. It is when they are so determined that a challenged election would be squared against the requirements it must meet before it is upheld as validly conducted. If it is thus squared and it meets the requirements, it was an election conducted in substantial compliance with the law and therefore must be upheld as

\footnotetext{
19 Electoral Act 2010 as amended in part iv

${ }^{20}$ Ibid, section 47

${ }^{21}$ Ibid, section 49 .

${ }^{22}$ Ibid, section 51 .

${ }^{23}$ Ibid, section 52 .

${ }^{24}$ Ibid, section 53(1).

${ }^{25}$ Ibid, section 54.

${ }^{26} \mathrm{Ibid}$, section 61 .

${ }^{27} \mathrm{Ibid}$, section 62 .

${ }^{28}$ Ibid, section 63 .

29 Ibid, section 64.

${ }^{30} \mathrm{Ibid}$, section 65 .

${ }^{31} \mathrm{Ibid}$, section 66.

${ }^{32}$ Ibid, section 69.

33 (2006) 2 WRN 123.

${ }^{34}$ Ibid.
} 
valid and if then it is an election conducted in substantial noncompliance with the law and therefore must be voided. ${ }^{35}$

The question that naturally follows is, what misconduct or noncompliance will a court or an election tribunal regard as amounting to substantial in relation to an election? Worst still, "substantial noncompliance and what substantially affects the result of an election" are not defined or explained in the Act. These have made them not capable of clear and precise definitions.

It appears now that noncompliance with the Electoral Act is not restricted to only a breach of the Act, but will extend to all acts capable of placing obstacle on the way of obstructing willing voters. This is the view of the Court of Appeal in Nwole v Iwuagwu, ${ }^{36}$ where the Court of Appeal held that it is not only the breach of Electoral Act that constitutes noncompliance. All acts capable of placing obstacle on the way or obstructing willing voters and candidate are acts of noncompliance.

Abdullahi, P.C.A in Buhari v Obasanjo ${ }^{37}$ brilliantly and scholarly summarized the principle guiding nullification of election on ground of non-compliance with the Electoral Act when he opined:

That an election ought not be voided by reason of transgression of the law committed without any corrupt motive by the electoral officials if the tribunal is satisfied that notwithstanding those transgressions, an election was really and in substance conducted under the electoral law, and the result of the election was not and could not have been affected by the transgressions. If on the other hand the tribunal sees that the effect of the transgression was such that an election was not really conducted under the existing election laws, or it is open to reasonable doubt whether those transgression may not have affected the results, and it is uncertain whether the candidate who has been returned has really been elected by majority of persons voting in accordance with the laws in force relating to elections, the tribunal is then bounded to declare the election void.

In other words, if at the end of the case of the petitioner in an election petition, a case of noncompliance is established which may or may not affect the result of the election and it is impossible for the tribunal to say whether or not the results were affected by the noncompliance established unless there is evidence on behalf of the respondent that such noncompliance as found could not and did not affect the result of the election, then the petitioner will be entitled to succeed on the simple ground that civil cases are proved by a preponderance of accepted evidence.

It must be noted that the principle that unless the result of an election is materially affected by an irregularity

\footnotetext{
${ }^{35}$ AK Usman, 'Buhari v Obasanjo: Law and Justice on the Cross', Ahmed Bello University, Zaria Journal of Public and International Law, p. 147.

would not be set aside is not peculiar to Nigeria alone. In the United States, "a successful challenge must prove that the irregularities changed the result of the election."38

It must be noted that section 138(2) of the $\mathrm{Act}^{39}$ needs to be looked into. It provides thus:

an act or omission which may be contrary to an instruction or directive of the Commission or of an officer appointed for the purpose of the election but which is not contrary to the provisions of this Act shall not of itself be a ground for questioning the election

The above provisions are self-explanatory. This is one of the bases, the INEC Card Reader machines, which were deployed by INEC during the 2015 General Elections, were declared not to be a basis for questioning an election petition, instead the usual manual voters' register.

Thus, the issue of when election cannot be questioned on the ground of non-compliance with instruction of INEC or its official came up in INEC v Peterside ${ }^{40}$ wherein the Supreme Court had no hesitation in doing the needful. In that case, the Supreme Court held that by virtue of section 138(2) of the Electoral Act, 2010 (as amended), an act or omission which may be contrary to an instruction or directive of the INEC or of an official appointed for the purpose of the election but which is not contrary to the provision of the Act shall not of itself be a ground for questioning the election. In effect, an infraction of a directive of the Commission which itself is not contrary to the provisions of the Electoral Act is not a ground for questioning an election.

In Maku $v$ Al-Makura, ${ }^{41}$ the Supreme Court adumbrated that where an election petition challenges the legality of the number of votes a candidate polled at the conclusion of an election on the basis of which scores the candidate was returned duly elected, it is incumbent on the petitioner, in addition to pleading material facts which constitute miscalculation of votes or falsification of results, to plead such other malpractices and non-compliance with the Electoral Act and to further lead evidence in support of the pleadings. It was further held that by section 138(1)(b) and 139(1) of the Electoral Act, 2010 (as amended), in an election petition, where a ground for challenging the return of a candidate in an election is by reason of corrupt practices or non-compliance with the provisions of the Electoral Act, the petitioner has the duty of proving:

(a) that the corrupt practice or non-compliance took place and,

(b) that the corrupt practice or non-compliance substantially affected the result of the election. $^{42}$

On when votes can be nullified at election, the Supreme Court held in Ikpeazu $v$ Otti ${ }^{43}$ that section 53(2) of the Electoral Act, 2010 (as amended) provides for nullification of votes at the polling unit if the votes cast in the polling unit

\footnotetext{
${ }^{38} \mathrm{BH}$ Weinberg, The Resolution of Election Disputes (Washington DC: IFES, 2006), p. 17.

${ }^{39}$ Ibid

${ }^{40}$ [2016] 7 NWLR (pt 1512) 555 at pp 571-572.

${ }^{41}$ [2016] 5 NWLR (pt 1505) 201 at 221.

${ }^{42}$ Maku v Al-Makura (supra) at 227.

${ }^{43}$ [2016] 8 NWLR (pt 1513) 38 at 82 and 83
} 
exceed the number of registered voters, and the conduct of another election could be ordered. It went further that it is in Form EC40C that the evidence of such cancellation and the ordering of a fresh election are always recorded. Section 53(3) of the Act provides that where election is nullified in accordance with section 53(2), there shall be no return for the election until another poll has taken place in the affected area. The Electoral Act does not contemplate disenfranchisement of a registered voter at an election how much more the exercise his right in post-election.

Having looked at the peripheral view of what non-compliance looks like, we shall now look at some of the specifics.

\section{ELECTORAL MALPRACTICES/CORRUPT PRACTICES}

Corrupt practices alternates with non-compliance as a ground for election petition. The Electoral Act, 2010 as amended does not specifically define what is meant by corrupt practices but there are sections in the Act where acts amounting to corrupt practices are set out. ${ }^{44}$ It is instructive to note that under the Electoral $\mathrm{Act}^{45}$ electoral malpractices constitute criminal offences and accordingly punishable under the Act.

Conduct amounting to electoral malpractice/corrupt practice and therefore punishable under the Act include: plural voting, forgery or unauthorized printing, manufacture, importation or use of ballot papers and ballot boxes; unlawful voting by a person not qualified to do so; bringing into a polling station a ballot paper issued to another person; voting in the name of some other person, whether such name is that of a person living or dead or of a fictitious person and other forms of impersonation; treating or the use of money after the date of an election has been announced to influence persons to vote or not to vote; undue influence or threat to use force, violence or other restraint or the infliction of injury; damage, harm or loss upon a person in order to induce or compel him not stand as a candidate or not to vote or otherwise impeded or prevent the free use of the vote by a voter, intimidation of voter through the possession of an offensive weapon or the wearing of an intimidating dress or decoration in a polling station or within 300 meters of it; bribery or the giving or promise of money (whether as a gift or loan), offices, employment, other patronage or valuable thing in other to induce a voter to vote or not to vote or on account of his having voted or refrained from voting; canvassing for votes in a polling station or within 300 meters of it; disorderly conduct at an election or incitement of it for the purpose of preventing or obstructing the conduct of the election and host of other. ${ }^{46}$

Needless to observe from the above instance that the phrase "Election malpractices" is not capable of a precise definition as it has a very wide connotation or an "elastic coverage." Professor Ben Nwabueze defines electoral malpractices as deliberate illegalities committed with a corrupt, fraudulent or sinister intention to influence an election in favour of a candidate or candidate by means such as illegal voting, bribery, treating and undue influence, intimidation and other acts of coercion exerted on voters, falsification of results, writing of results without election,

\footnotetext{
${ }^{44}$ Part viii, Section 117 - 131 of the Electoral Act 2010 as amended.

${ }^{45}$ Ibid.

${ }^{46}$ Ibid.
}

snatching of electoral material etc ${ }^{47}$. Similarly JTU Nnodum defines election malpractice as any act or conduct which is a transgression of the relevant statutory provisions for the particular election aimed at impeding a free and fair election exercise. $^{48}$

The above two definitions are similar. The common elements in the two definitions are that electoral malpractices have an objective of unduly influencing the outcome of an election and they are always committed deliberately with this objective in view. In Yusufv Obasanjo, 49 PATS-ACHOLUNU, JSC, opined that "corrupt practices connotes and embrace certain perfidious and debauched activities which are really felonious in character being redolent in their depravity and want of ethics. They become the hallmark of a decayed nature lacking in conscience and principle." It is worthy of note that some of the earlier electoral Statues ${ }^{50}$ specifically defined "corrupt practice" to mean the offences of:
i. Personation;
ii. Treating;
iii. Undue influence; or
iv. Bribery
$v$. Aiding, abetting, counselling or procuring the commission of any the offences in paragraph $a-d .^{51}$

Notwithstanding, the fact that Electoral Act, 2010 as amended has not specifically defined "corrupt practices" it is clear from the import and purport of the provisions of section $117-131^{52}$ that acts of personating, treating, undue influence, and bribery will come with the wordings of these sections.

Aside from the offences that come within the meaning of corrupt practices, all other electoral offences that are capable of undermining the result or outcome of an election, though not punishable as crime, are also, if proved beyond reasonable doubt, capable of giving rise to the nullification of the result of an election. Commission of offences amounting to corrupt practices and other electoral offences are instance of noncompliance with the Electoral Act. $^{53}$

\section{ELECTORAL MALPRACTICES AND ELECTORAL IRREGULARITIES}

Electoral irregularities relate to non-compliance with prescribed procedure for an election. It may or may not be an offence. Example of electoral irregularities include: polling outside the statutory stipulated time, late delivery or shortage of electoral materials, failure to provide them. Professor Nwabueze postulated that in great majority of cases electoral irregularities are not deliberately committed. This is one

${ }^{47}$ BO Nwabueze, Nigeria Presidential Constitution (1919 83) the Second Experiment in Constitutional Democracy (London: Longman, 1985), p. 401.

${ }_{48} 9$ JTU Nnodum, Election Petitions: Law and Practice (Lagos: James Alice Service Ltd, 1996), p. 88.

${ }^{49}$ (2003) 16 NWLR (pt 847) 554.

${ }^{50}$ For example Section 61(3) of the Local Government

(Constitution Transition) Provision Decree No. 36 of

1998.

${ }^{51}$ Ibid

${ }^{52}$ Electoral Act 2010 as amended.

${ }^{53}$ Aderemi, Election Law and Practice in Nigeria (Akure: Aderemi Olatunbora \& Co, 2006), p. 113. 
factor which distinguishes electoral irregularities from electoral malpractices. He also made another distinction between electoral irregularities and malpractices. To him, the legal consequences of electoral irregularities and electoral malpractices differ, whilst the latter do not, in general, invalidate an election, the former emphatically do. ${ }^{54}$

Electoral irregularities are those acts or omissions which are contrary to the electoral laws or rules. In this sense, electoral irregularities will include electoral malpractices since all malpractices are invariably contrary to rules.

It is however, suggested that where an act or omission is contrary to the electoral law or rule and is either deliberated or with a motive to cheat, such act or omission should be regarded as electoral malpractice. On the other hand, where the failure to follow the electoral law or rules is neither deliberate nor activated by a motive to cheat, it should be characterized as electoral irregularities. ${ }^{55}$

\section{Respondent Not Duly Elected by Majority of Lawful Votes}

Ground 138(1) (c) of the Act provides: "that the respondent was not duly elected by majority of lawful votes cast at the election". This is a ground wherein the tribunal/court is enjoined to remove votes gotten unlawfully and decipher who has the highest number of lawful/valid votes to arrive at the person who actually won the election, having satisfied other conditions of the law and be declared and returned as the winner.

In Ikpeazu $v$ Otti $^{56}$ it was held that to prove over-voting, the petitioner must do the following:

(a) tender the voters' register;

(b)tender the statement of results in the appropriate forms which would show the number of accredited voters and number of actual votes;

(c) relate each of the documents to the specific area of his case in respect of which the documents are tendered;

(d) show that the figure representing the over-voting, if removed, would result in victory for the petitioner. ${ }^{57}$

On Importance of voters register in proof of number of voters in an election and effect where not tendered, the Supreme Court in Okereke v Umahi ${ }^{58}$ held thus:

In this case, the appellant chose not to utilise the Voters' Register to show the entire gamut of the voters. Rather he built his case on inaccurate, insufficient electronic data, exhibit GP45, which is not comprehensive enough to be relied upon in proof of the allegation of non-compliance with the Electoral Act, 2010.

Consequently, the Supreme Court invoked the provisions of section 167(d) of the Evidence Act, 2011 against the appellant withholding evidence of voters' register.

\footnotetext{
${ }^{54} \mathrm{BO}$ Nwabueze, op cit, 401.

${ }^{55}$ MT Laden and AI Kiru, Election Violence in Nigeria (Afstrag Nigeria, 2005), p. 20.

${ }^{56}$ Supra at 88 and 92

${ }^{57}$ See also Nyesom v Peterside [2016] 7 NWLR (pt 1512) 452 at 551; Yahaya $v$ Dankwanbo [2016] 7 NWLR (pt 1511) 284 at 313, 314 and 337; Ladoja v Ajimobi [2016] 10 NWLR (pt 1519) 87 SC; Emerhor v Okowa [2016] 11 NWLR (pt 1522) 1 SC; Ogboru v Okowa [2016] 11 NWLR (pt 1522) 84 SC ${ }^{58}$ [2016] 11 NWLR (pt 1524) 438 at 475-476.
}

Hence, in proof of an allegation of over-voting, the petitioner bears the responsibility of calling eye-witnesses from each polling unit to give evidence of the circumstances that led to the over-voting, preferably party agents. Over-voting can only be demonstrated clearly where the number of accredited voters is less than the number of voters or votes cast. It is not enough for the petitioner to allege and prove over-voting. In addition to the above the petitioner must show that the said over-voting inured to the winner of the election in particular as the over-voting can be for any of the candidates in the election, respondent or any of the other contestants in the election in question. The court must also be satisfied that it was due to the over-voting traceable to the respondent that the respondent won the election.

More so, in Ikpeazu $v \mathrm{Otti}^{59}$ the relevance of card reader in proof of over-voting was considered wherein it was held that section 49 of the Electoral Act, 2010 (as amended) states that a person would be allowed to vote if, and only if, his name is in the voters register. On the other hand, the card reader, the brainchild of the former head of the INEC, has no statutory backing like the voters register. It was introduced to improve the accreditation process. It does not violate any law. Where a petitioner seeks to prove that there was over-voting in the election in which he participated, he would succeed if he is able to show that the number of votes exceeds the number of would be voters in the voters register. If the petitioner decides to rely on a card reader report, as in the instant case, to show that the number of votes exceeds the number of voters recorded by the card register, he would fail. The card reader may be the only authentic document if and only if the National Assembly amends the Electoral Act to provide for card readers. It is only then that card readers would be relevant for nullifying elections.

It is to be noted that the ground as envisaged in section 138(1)(c) is the only ground inuring to a successful petitioner to be declared as the outright winner and be returned as such after satisfying other qualifications of the law. This position is in tandem with section 140(3) of the Act, ${ }^{60}$ which provides thus:

If the Tribunal or the Court determines that a candidate who was returned as elected was not validly elected on the ground that he did not score the majority of valid votes cast at the election, the Election Tribunal or the Court, as the case may be, shall declare as elected the candidate who scored the highest number of valid votes cast at the election and satisfied the requirements of the Constitution and this Act

Valid Nomination But Unlawful Exclusion

Ground 138(1)(d) provides thus: "that the petitioner or its candidate was validly nominated but was unlawfully excluded from the election". This provision inures to the political party (as the petitioner) where, either the party's logo or party's name, et cetera was excluded in the election. This was the situation in People for Democratic Change (PDC) \& Anor v Chief Martins Elechi \& 5 Ors, ${ }^{61}$ which emanated under the 2011 General Elections for the Gubernatorial

\footnotetext{
${ }^{59}$ Supra at $100-101$.

${ }^{60}$ Ibid

${ }^{61}$ EB/EPT/GOV/2/2011.
} 
election in Ebonyi State wherein Chief Kevin Opoke was the gubernatorial candidate of PDC while Chief Martins Elechi was the candidate of PDP among others. In that election, the PDC's logo, which had Chief Opoke as candidate was missing while other political parties which fielded candidates were featured. Chief Opoke (candidate) himself filed Petition No EB/EPT/GOV/2/2011 and included the name of his political party without the consent of his political party wherein he was the 2nd petitioner. Chief Opoke's party, PDC subsequently filed petition no EB/EPT/GOV/3/2011 and became the sole petitioner. The two petitions did not see the light of the day: EB/EPT/GOV/2/2011 was dismissed in limine because of non-filing of application for issuance of pre-trial conference while EB/EPT/GOV/3/2011 was also dismissed because of abuse of court process.

Though the two petitions as stated above died out of technicalities, but it is a good case of presenting an election petition under section 138(1)(d) of the Electoral Act.

It is the opinion of the researcher that the right to present election petition under section 138(1)(d) of the Act inures to the political party only and not to the candidate based on the wordings of the said section. The political party alone can file the petition in her name or jointly with the name of the candidate. However, the candidate cannot file the petition alone or solely join his/her political party without the consent of the political party based on the wordings of the said section in question. This is only thing apposite to avoid a situation of what happened in EB/EPT/GOV/2/2011 and EB/EPT/GOV/3/2011 as stated above.

It is to be noted that where this ground of petition is established, the tribunal/court shall only have the right to nullify the election. This is in tandem with section 140(1) of the Act, ${ }^{62}$ which provides thus:

Subject to subsection (2) of this section,

if the Tribunal or the Court as the case may be, determines that a candidate who was returned as elected was not validly elected on any ground, the Tribunal or the Court shall nullify the election.

To successfully prove any of the grounds of challenging an election petition under section 138 of the Electoral $\mathrm{Act}^{63}$ the concept of burden and standard of proof need to be understood and appreciated. Burden and standard of proof are twin expressions in the adjectival law of proof in evidence. In their twin relationship, they both jointly enhance proof of cases in court. The party on whom the burden of proof lies has the obligation to persuade the court in the best tradition of advocacy of the veracity or authenticity of the fact he relies upon. In order to satisfy or discharge the obligation he must adduce enough evidence to push the pendulum to his side. ${ }^{64}$

\section{Burden of Proof of Non-Compliance}

The burden of proof in an election petition is on anyone questioning the results of an election to establish his claim. Thus a petitioner in an election petition who alleges in his petition a particular noncompliance must satisfy the court/tribunal that the noncompliance is substantial and affects substantially the result of the election. The position is

\footnotetext{
${ }^{62}$ Ibid

${ }^{63}$ Electoral Act 2010 (as amended).

${ }^{64}$ A Babalola, Law and Practices of Evidence in Nigeria (Ibadan: Sibon Books Ltd, 2007), p. 275.
}

based on evidential principle that he who assert must prove. ${ }^{65}$ In Buhari v Obasanjo ${ }^{66}$ the Supreme Court held that, where an allegation of noncompliance with the electoral law is made, the onus lies on the petitioner firstly to establish the substantial noncompliance; and secondly that the non-compliance did or could have affected the result of the election. The onus will only shift after the petitioner has established the noncompliance, to the respondent whose election is challenged to establish that, the result was not affected after all. The Supreme Court further opined that where a petitioner makes noncompliance the foundation of his complaint he is fixed with a heavy burden to prove before the tribunal by cogent and compelling evidence "that the noncompliance is of such nature as to affect the result of the election."

In Ughamadu $v$ Ndibe ${ }^{67}$, the court observed thus: The onus is on the petitioner who is alleging noncompliance with a particular provision of the law to prove his case. He is expected to establish the following:

(i) that there was noncompliance with the provision of the Electoral law. He must state the provision of the law and the noncompliance therefore.

(ii) that the noncompliance complained of affected substantially, the result of the election. That is, he must state that if not for the noncompliance the petitioner would have won the election. Also he must state that the noncompliance have deprived the petitioner of valuable votes that could have accrued to him in the election.

In Maska v Ibrahim, ${ }^{68}$ where the petitioner alleged inter alia that the vice-chairman elect of a local government was an ex-convict; the Court of Appeal held:

A person who alleges must prove the substance of his allegation. In the instant case, since the identity of the $2^{\text {nd }}$ respondent vis -a-vis the vice chairman elect is put in issue, it is the duty of the appellant to prove same on the balance of probabilities. The appellant have failed to discharge this duty to show that the vice chairman elect is the same person as Shehu Maska, who was established on the record to have been convicted.

Also in Aondoaka $v$ Ajo $^{69}$ where the respondent alleged that PW 1 is an impersonator but did not put the question to him under cross examination, the Court of Appeal held that the respondents failed to discharge the onus put on them under the law.

The view of Mohammed J.C.A in Abba $v$ Jumare ${ }^{70}$ on the issue of onus of proof of an allegation is very

\footnotetext{
${ }^{65}$ Section 131 of the Evidence Act, 2011

${ }^{66}$ Supra.

${ }^{67}$ (2010) 46 WRN 55.

${ }^{68}$ [1999] 4 NWLR (pt 599) 415.

${ }^{69}$ [1995] 5 NWLR (pt 602) 206.

${ }^{70}$ [1999] 5 NWLR (pt 602) 270.
} 
instructive. The Learned Justice of the Court of Appeal posited thus:

The trite law is that where there is an allegation of the existence of a particular fact, it is the duty of the person who alleges to prove his allegation. S 135 (1) of the Evidence Act states: whoever desire any court to give judgment to any legal right or liability dependent on the existence of the facts which he assert must prove that those facts exist.

Thus since the appellant asserted non-compliance with the provision of section 11(1) (f) of the Decree, they ought to have proved payment of salary in lieu of resignation 30 days before the election date. I agree with the tribunal that the non-production of the receipt PW3 stated in his evidence in chief he issued to the $1^{\text {st }}$ respondent on $23 / 11 / 1998$, as exhibit at the trial is indeed fatal to the petition. Further, where a party refused to produce evidence that is material which is required to prove certain facts which are within the knowledge of a witness as is the case here, it is presumed that such evidence if adduced will be unfavourable to the person withholding it.

Similarly, Belgore, JSC (as he then was) appeared to have summarized the applicable principle when the court or tribunal is confronted with the question of burden of proof in election petition cases. Justice Belgore in interpreting section 135 (1), Electoral Act $2002^{71}$ in Buhari $v$ Obasanjo ${ }^{72}$ opined as follows:

It is manifest that an election by virtue of section 135 (1) of the Act shall not be invalidated by mere reason it was not conducted substantially in accordance with the provision of the Act, it must be shown clearly by evidence that the noncompliance substantiality has affected the result of the election. Election and its victory, is like soccer and goal scored. The petitioner must not only show substantial noncompliance but also the figures. That is, votes that compliance attracted or omitted. The elementary evidential burden of "the person asserting must prove has not been derogated from by S. 135(1). The petitioners must not only assert but must satisfy the court the noncompliance has affected the election result to justify nullification. The onus has not by any means shifted from the time honoured law on evidence that the person who assert a situation must prove. The burden on petitioner to

${ }^{71}$ Which is impari materia with section $139(1)$ of the Electoral Act 2010 as amended.

${ }^{72}$ Supra. prove that noncompliance has not only taken place but also substantially affected the result must be fulfilled. There must be clear evidence of noncompliance, then that noncompliance has substantially affected the election.

The net effect of the highlighted dictum of eminent Justices of Court of Appeal and Supreme Court is that a person challenging the return at an election on ground of noncompliance with the provision of the Electoral Act has the singular onus of proving not only the substantial noncompliance but must go further to show how the alleged substantial noncompliance affected the result of the election.

It must be appreciated that although the chain of cases cited above seem to suggest that onus of proof is always on the petitioner and never shifts, however there are exceptions to this evidential principle as there are instances in which the onus would shift. Once a petitioner establish noncompliance, and the court cannot say whether or not the result of the election could have been affected by the noncompliance, the onus shifts to the respondent to show that the noncompliance did not affect the result of the election. ${ }^{73}$

From the discourse above it is evidently clear that a return to an election will not be voided if it appear to any court hearing the petition which challenges the return that there was substantial compliance as used in the Act and restated in judicial authorities does not mean absolute compliance but "considerable compliance." 74

\section{Burden of Proof of Corrupt Practices/Electoral Malpractices}

Where a petitioner in an election petition alleges electoral malpractice, the onus of proof rest squarely on that petitioner to prove the malpractice alleged and to show such malpractice has affected the result of the election. It has been held in plethora of judicial authorities that the burden of proving criminal offence in an election petition is on the petitioner. In Ughamadu $v$

$N_{d i b e}{ }^{75}$ the court held that "an allegation of corrupt practices during an election amounts to an allegation of a criminal act; and the petitioner who makes such allegation has the onus to prove the allegation beyond reasonable doubt as provided under section 138 of the Evidence Act."

In Eze v Okoloagu ${ }^{76}$ the court reiterated the principle of evidential burden thus: The petitioner must not only prove the alleged corrupt practices and malpractices, but he must show that same was committed in favour of the winner of the election with knowledge or consent by person acting under his general or special authority, this is because no one can be punished for crime of another.

\footnotetext{
${ }^{73}$ Swen v Dzengwe [1996] NWLR 297; Abubakar v Yar'Adua [2008] 19 NWLR (pt 1120) 1.

${ }^{74}$ Angbazo v Egbe [1993] 1 NWLR (pt 268) 133.

${ }^{75}$ Supra

${ }^{76}$ [2010] 3 NWLR (pt 1180) 183.
} 
In Falae $v$ Obasanjo $^{77}$ the Supreme Court went extreme when it held that the law is that even if a political party engaged in criminal activities which would disqualify a candidate it cannot affect -the candidate unless is shown that the candidate authorized or ratified the offending conduct. This decision in the writer's opinion is unreasonable and unhelpful to the principle of requirement of proof in election. What more does the court need in proof when the candidate is not an independent candidate and relies on the party to contest election.

Similarly in Buhari v Obasanjo, ${ }^{78}$ the Supreme Court further opined thus: Irregularities at an election which are neither act of a candidate nor link to him cannot affect his election. Therefore an elected candidate cannot have his election voided on the basis of corrupt practices or any other irregularity committed in the process of the election unless it can be proved that the candidate expressly authorized the illegality.

In a simple language therefore, for a petitioner to succeed in a petition founded on corrupt practices, he has the onus of proving the following beyond reasonable doubt:

(a) That the respondent personally committed the corrupt act or aided, abetted, counsel or procured the commission of the alleged act of corrupt practice. Where the alleged act was committed through an agent, that the agent was authorized to act in the capacity or granted general authority.

(c)

That the alleged corrupt practice had an effect on the outcome of the election, that if the votes scored through the acts of corrupt practices are deducted from the votes scored by the respondent, the result of the election would have changed.

Worse still, the Supreme Court appeared to be positing that where a petitioner alleges corrupt practices by soldiers, police or thugs, the petitioner must be able to identify and even join them in the petition. This is what the Supreme Court had to say:

The allegation made against unidentified policemen and soldiers are criminal in nature, as well as the alleged thugs of the $3^{\text {rd }}$ respondent whom the petitioner also tried to incriminate, have also not been identified; also of all the witness called by the petitioners none of them specifically identified any police officer or soldier; accordingly no allegation of crime can be established with the scenario by the petitioners. $^{79}$

It is evident from the chain of judicial authorities cited above, that it is very herculean and an uphill task having to prove an offence of corrupt practice so as to nullify an election. It is the researcher's humble view that the postures assumed and maintained by courts/tribunal are rather too strict so much that it can be said to encourage the electoral malpractices. It is suggested that a dispassionate and fair position should be adopted when treating cases of electoral malpractices. That is, once irregularities are established and sufficient to void an election, the tribunal/court should discountenance with the

\footnotetext{
${ }^{77}$ [1999] 4 NWLR (pt 599) 476.

${ }^{78}$ Supra

${ }^{79}$ Buhari v JNEC (Supra).
}

requirement that it must be perpetuated by the respondent or aided or sanctioned by him/her.

Also, one of the evidential imperatives in election petitions, which appear to be an albatross to cutting down the number of witnesses in election petitions as being formulated by the courts/tribunals is the law on bringing up witnesses in each polling unit if it involves questions on what transpired in the polling units. ${ }^{80}$

These cases were decided under the old electoral laws that did not provide a timeframe for hearing and determination of election petitions. However, to the chagrin of watchful eyes, even with the introduction of the timeframe (180 days) for filing and determination of a petition under the recent amendment to the Constitution, ${ }^{81}$ the Supreme Court in Gundiri v Nyako ${ }^{82}$ still went ahead and held that where a petitioner complains of non-compliance with the provisions of the Electoral Act, the petitioner has a duty to prove the non-compliance alleged based on what happened at each polling unit ${ }^{83}$. The import of that duty is that the petitioner has to call witnesses who were at each polling unit during the election or in the alternative present the polling agents' report before the tribunal. ${ }^{84}$

With utmost respect to the learned Justices of the Supreme Court, the above dictum does not seem to be in agreement with evidential principle of quality and not quantity of witnesses. It is an elementary principle of law that winning or losing a case does not depend on the number of witnesses called by a party but on the probative value of their evidence. This was the ratio in Ogunyombo v Okoya. ${ }^{85}$

\section{CONCLUSION}

An examination of the Electoral Act and a study of decided authorities on electoral matters reveal that a petitioner has a difficult task proving his petition in accordance with the Electoral Act. It is very difficult to prove criminal allegations beyond reasonable doubt. That explains why I am firmly of the view that the Electoral Act should be amended to shift the burden of proof to the Independent National Electoral Commission. It should be their burden to prove that they conducted an election properly.

\section{RECOMMENDATION}

So based on the problems encountered in the election petition cases in Nigeria, the following recommendations are made:

1. Further amendment of the Electoral Act is advocated to shift the burden of proof to the Independent National Electoral Commission (INEC) to prove that they conducted an election properly. This stems from the examination of the present Electoral Act and a study of decided authorities on electoral matters, which reveal that a petitioner has a difficult task

\footnotetext{
${ }^{80}$ See Chime vEzea [2009] 2 NWLR (pt 1125) 263 at 357. See also Ayogu v Nnamani[2QQ6] S NWLR (pt 981)

160 at 194; Okoroji v Ngwii [1992] 9 NWLR (pt 263) 113;

Buhari v Obasanjo (Supra).

${ }^{81}$ Section 285(6) of the Constitution of the Federal Republic of Nigeria 1999 (as amended)

${ }^{82}$ [2014] 2 NWLR (pt 1391) 211

${ }^{83}$ Emphasis mine.

${ }^{84}$ Gundiri v Nyako supra; Ucha v Elechi (Supra).

${ }^{85}$ [2002] 16 NWLR (pt 793) 224.
} 


\section{Evidential Imperatives in Election Petitions in Nigeria}

proving his petition in accordance with the Electoral Act. It is very difficult to prove criminal allegations emanating from the conduct of elections beyond reasonable doubt in an environment where the whole facts including the documents to be relied upon are in possession of the INEC.

3. Discharged on the balance of probabilities. This is because the main intention of the election petitioner is to nullify an election and fresh one conducted or be declared an outright winner and not necessarily to convict the respondent. Evidence of commission of crime in election petition should not be seen to be directly in issue but ancillary to the grounds upon which an election petition is presented. If INEC or the Attorney General of the Federation intends to prosecute a respondent who committed electoral offences, that is a different proceeding and that is when the electoral offences should be proved beyond reasonable doubt.

4. The mere fact that it can be established that an election is riddled with corrupt practices not linked with the election petitioner or his/her supporters should be sufficient enough to void such an election without necessarily establishing the link between the respondent and the persons who carried out the corrupt practices.

5. A situation may arise where election petitions are not concluded before the date for swearing in of
2. In the alternative, further amendment of the Electoral Act or the amendment of the Evidence Act, 2011 is advocated to make every burden of proof (whether civil or criminal) in election petition to be

successful candidates despite the fact that enough time has been provided for concluding election petitions. In such situation there must be provision in the Constitution and/or Electoral Act to the effect that in the case of Presidential election and Governorship election, the Chief Justice of Nigeria or the Senate president and the Chief Judge of the State or the Speaker of the State House of Assembly respectively should be sworn in pending the determination of election petition. In the case of the National Assembly and States House of Assembly elections, there must be law suspending the representation of the Senatorial zone or Constituency concern till the determination of the election petition.

6. The Electoral Act should be further amended to include in its interpretation section the meaning of concepts such as "compliance", "noncompliance", "substantial compliance", "substantial noncompliance" and "corrupt practices". It is hoped that such definitions will bring to the fore in clear and unambiguous manner the intendment of the legislature for providing for such terminologies in the Act and also obviate the subjective interpretations always given to those terminologies. 